\title{
Paideusis
}

\section{"Philosophy of Education: Introductory Readings (3rd Edition)" (William Hare and John Portelli (Editors))}

\section{Linda Farr Darling}

Volume 15, Number 1, 2006

URI: https://id.erudit.org/iderudit/1072697ar

DOI: https://doi.org/10.7202/1072697ar

See table of contents

Publisher(s)

Canadian Philosophy of Education Society

ISSN

0838-4517 (print)

1916-0348 (digital)

Explore this journal

Cite this review

Darling, L. (2006). Review of ["Philosophy of Education: Introductory Readings (3rd Edition)" (William Hare and John Portelli (Editors))]. Paideusis, 15(1),

95-101. https://doi.org/10.7202/1072697ar

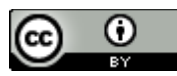

This document is protected by copyright law. Use of the services of Erudit (including reproduction) is subject to its terms and conditions, which can be viewed online.

https://apropos.erudit.org/en/users/policy-on-use/ 
Review of

\title{
Philosophy of Education: Introductory Readings (3 $3^{\text {rd }}$ Edition)
}

by William Hare and John Portelli (Editors), Calgary: Detselig Enterprises, Ltd., 2001Publisher.

\author{
LINDA FARR DARLING \\ University of British Columbia
}

The invitation to review Philosophy of Education: Introductory Readings, was like an invitation to sit with old friends who have a lot to tell you, only some of which you've heard before (and don't mind hearing again, even when you disagree). Knowing some new friends were coming along added to the anticipation of a good chat. This three-part essay is my attempt to put responses generated by the twenty-six readings into a review of my hopes and concerns about the enterprise of doing philosophy of education, including the task of encouraging aspiring teachers (and reminding ourselves) to be philosophers of our own educations. ${ }^{1}$ Part One of this essay is about the book's structure and entries; Part Two is about beliefs of aspiring teachers to whom the book is largely addressed, and Part Three is concerned with the larger philosophical and pedagogical context into which the book fits.

\section{The Entries and Their Aims}

The introduction promised I would find impetus for lively debate about crucial issues in education, and I was rarely disappointed, though I probably spent too much time talking back to Richard Rorty, and trying to second-guess Jane Roland Martin (hasn't anything changed since the mid-eighties?). Editors William Hare and John Portelli have replaced half the entries from the $2^{\text {nd }}$ edition with new contributions, reflecting a shift in emphasis, and awareness of the fluidity of political and social contexts into which philosophers of education wade. There are seven sections: Theory and Practice; Conceptions of Education; Avoiding Indoctrination; Critical Thinking and Teaching; Controversy in the Classroom; Democracy and Pluralism in Education; and Standards in Education. The largest number of entries are in the section on democracy and pluralism which won't surprise readers who know John Portelli's work on democracy, and William Hare's interest in the virtue of open-mindedness and what it means in (and to) a liberal society. One of the smallest sections is on developing and defending educational standards, which arrives almost as an afterthought. With tensions in the area of accountability rising, even a brief word is welcome. There is a logical order to the sections; questions that are raised by one set of discussions flow smoothly to the next. At every section, an opening passage provides a conceptual bridge between central questions and the papers. A recommended reading list is a useful addition to each opening passage. The Editors have done uncommonly

\footnotetext{
1 Ann Diller, "Facing the torpedo fish: Becoming a philosopher of one's education," retrieved from http:// www.ed.uiuc.edu/eps/PES-Yearbook/1998/diller.html.

(C) Copyright 2006. The author, Linda Farr Darling, assigns to Paideusis the right of first publication and educational and nonprofit institutions a non-exclusive license to use this document for personal use and in courses of instruction provided that the article is used in full and this copyright statement is reproduced. Any other usage is probibited without the express permission of the author.
} 
thoughtful work in three areas: identifying key issues in philosophy of education that can be fruitfully organized into sections, selecting articulate spokespersons to represent various viewpoints, and providing useful commentary to bring coherence to the volume. In this way, the introductory readings, taken as a whole, become a useful entry point for anyone who is curious about the problems that perennially intrigue philosophers of education.

Part One offers two sets of remarks on the relationship of theory to practice; they are, in a sense, justifications for the book itself. Harold Entwistle, who admits to having thought about these issues for some time, presents both familiar and new commentary. Among the important lessons are his reminders of the limits and possibilities of theory including the reminder that theories must be applied creatively and with sensitivity to the realities and compromises of the classroom. Much theory wrongly assumes that classrooms are autonomous associations "in which the teacher is able to function independently, without bureaucratic constraints upon one's professional judgment and competence." 2 Entwistle notes (importantly) that despite the fact that schools are all about grouping people, "liberal educational theory is overwhelmingly individualistic in orientation." 3 I immediately thought of Dewey's more socially-oriented pedagogy, which, as it happens, was discussed in the next entry.

Douglas Simpson revisits Dewey on the connections, intersections and disjuncture of theory, practice and research. Theorizing, researching, and learning new theories give one the "power to go on growing." In contrast, "[E]xclusive preoccupation with matters of use and application narrows the horizon and in the long run defeats itself. It does not pay to tether one's thoughts to the post of use with too short a rope." ${ }^{4}$ Calling for a laboratory view of theory and practice, Simpson tells us that educators need to continually test the value of particular theories for own purposes and practices, within a professional community of inquirers, a recommendation that readers of philosophy of education might heed in Parts Two through Seven of this very book.

Part Two takes up the perennial question, "What's the use of going to school?" by presenting conceptions of education from writers who might be considered spokespersons for various positions, including romantic, humanist, feminist, and communitarian perspectives. Such well-known educational philosophers as Maxine Greene and Jane Roland Martin join other voices to enrich a conversation that has a venerable history; Douglas Stewart's piece on humanization brings some of this history into a distinctly Canadian context. On his account humanization includes moral and emotional as well as intellectual components, and Stewart provides a lovely list of what the "journey" toward becoming human might entail. Candace Jesse Stout gives empathy an extremely expansive role in her conception of education; she holds out possibility that an arts-based education will avoid the pitfalls of the traditional liberal education Jane Roland Martin so harshly criticizes in a paper from 1985. Richard Rorty, well-known for dismissing philosophy of education entirely, has a piece on socialization and individuation which seems to me to oversimplify complex issues by failing to acknowledge the inevitable relationships between the two educational processes he describes.

A useful addition to this section might be a contribution from social epistemologist, Alvin Goldman, or another articulate exponent of the view that education is most fundamentally about the acquisition of knowledge in the form of justified true beliefs. ${ }^{5}$ The omission of this "enlightenment" view is particularly evident as the intellectual heart of the book is located in part in Harvey Siegel's famous definition of a critical thinker as one who is "appropriately moved by reasons." All the

\footnotetext{
${ }^{2}$ Harold Entwistle, "The relationship between educational theory and practice: A new look," in W. Hare and J.Portelli (eds.), Philosophy of Education: Introductory Readings, Revised Third Edition (Calgary: Detselig Ent. Ltd. 2001), 21-22.

${ }^{3}$ Ibid, 21.

${ }^{4}$ Douglas Simpson, "The relationship of educational theory, practice, and research," in W. Hare and J.Portelli (eds.), Philosophy of Education: Introductory Readings, Revised Third Edition (Calgary: Detselig Ent. Ltd., 2001), 31.

${ }_{5}^{5}$ See Alvin Goldman, Chapter 5 on Argumentation and Chapter 11 on Education, in Knowledge in a social world (London: Oxford University Press, 1999).
} 
contributors to the collection, whether they identify themselves as postmodernists, liberals or other, are engaged in the enterprise of trying to "appropriately move" readers by presenting arguments based on reasons they believe are compelling.

Part Three on Indoctrination, Part Four on Critical Thinking and Teaching, and Part Five on Controversy in the Classroom, examine belief acquisition and revision, the relationship between belief and knowledge, and the ethics of trying to change beliefs. Indoctrination is discussed from several angles, starting with the Editors' caution that the distinction between indoctrinating and teaching is more problematic than might first be supposed. Pedagogical integrity requires that we respect children's rights to grow into adults who are "able and willing to think seriously about life-shaping choices." 6 Eamonn Callan contributes a characteristically careful treatment of ethical and pedagogical factors relating to parental rights and indoctrination. His paper is followed by Joyce Bellous' dynamic discussion of resistance and empowerment, and an impassioned 1985 interview with Paulo Freire on related themes.

If I were assigning readings, some choices would come from the next section, particularly the readings on contested notions of critical thinking, not only because of perspectives presented, but because the term is a good example of educational slogans that need to be unpacked with care. Following Carl Sagan's musings on wonder and skepticism, Sharon Bailin writes about the essential and intriguing relationship between creativity and critical thinking still missed in the literature. Harvey Seigel's well-reasoned article on prejudice as a failure to think critically is followed by provocative papers by Blythe Clinchy and Barbara Thayer-Bacon. Both attend to relational aspects they believe are neglected in the familiar concept of critical thinking: Clinchy responds with her notion of connected knowing, which holds promise but seems underdeveloped in this paper. Thayer-Bacon calls "constructive thinking" a transformation of critical thinking. The social dimensions of her conception offer a welcome shift in emphasis, but might still be compatible with more standard views. For example, Ann Margaret Sharp's portrait of an ideal community of inquiry in action (next section) reflects similar commitments, though she would maintain that dialogical tensions are vital to intellectual growth, where Thayer-Bacon might try to ease the same tensions. The section on Controversy contains illuminating analyses of two famous Canadian cases (William Hare on Keegstra and Sheva Medjuck on Malcolm Ross). Possible approaches to teaching controversy are outlined by Thomas Kelly who argues for one with the intriguing name, "committed partiality."

Part Six, Democracy and Pluralism in Education, is understandably dense. Democracy and education are "essentially contested concepts" and when you throw pluralism into the mix, the picture becomes even messier. Portelli begins with a straightforward overview of rather extreme conservative and progressive stances toward the role of democratic practices in education, insightfully concluding that neither stance captures the reciprocal and fluid relationships between education and democracy. There is a glimpse of Portelli's preferred vision of the relationship based on Dewey's notion of "democracy as a way of life," a theme Portelli has explored elsewhere in more depth. Sharp vividly describes commitments and behaviors needed for participation in an ideal community of inquiry - a challenging, even exhausting list to contemplate for classrooms. While she explores a wide spectrum of emotional, intellectual and moral dispositions, Heesoon Bai examines, in a subtle and spiritually-infused piece, just one moral virtue for democratic participation: intersubjectivity. Obstacles to its cultivation are identified, but do not intrude on her hopeful tone. Callan opens by revisiting Dewey's question: "What suitably rich and inspiring vision of a shared educational venture could inform schooling in a diverse and democratic society?" 7 His investigation takes up the separatist challenge, the problems with the consensual conception for common schools, and finally, the hope that might be found in Rawl's

\footnotetext{
${ }^{6}$ W. Hare and J.Portelli (eds.), Philosophy of Education: Introductory Readings, Revised Third Edition (Calgary: Detselig Ent. Ltd., 2001), 118.

7 Eamonn Callan "Indoctrination and Parental Rights," in W. Hare and J. Portelli (eds.), Philosophy of Education: Introductory Readings, Revised Third Edition (Calgary: Detselig Ent. Ltd., 2001) 121-130.
} 
notion of public reason, and the virtue of reasonableness. (I don't believe these necessarily co-exist.) Also contemplating the possibility of shared educational ventures in a pluralist society, Paul Bitting asks philosophers to account for their own philosophical paradigms and educational practices that restrict multiple visions of the world and extend the meaning of difference rather than help people cope with differences. There are many assumptions to uncover before we can meaningfully transform education into an enterprise that is truly multicultural. Romulo Magsino concludes the section with a thoughtful reevaluation of Canada's multicultural policy in light of several of its most vocal critics, arguing that the ethical imperative is stronger than ever.

Part Seven, Standards in Education, includes two contributors (Elliot Eisner and Nel Noddings) who weigh in on much the same side of a growing and politically-drenched debate. The strengths of both entries are the illuminating references to educational history, and the fact that both authors conceptualize standards as values that we should examine in light of other things that we cherish.

\section{Aspiring Teachers' Beliefs about Teaching}

I responded to the book as someone who places herself (part way) inside the practice of philosophizing about educational questions and problems. The issues matter to me, as they clearly do to the contributors. I also like to turn over rocks to see what's underneath. However, the book is not mainly intended for someone like me, but as introductory reading for aspiring teachers. In my experience, preservice teachers are not typically intrigued by the prospect of turning over these rocks. They view the enterprise of learning to teach as something altogether separate from learning about the ways people conceptualize educational aims and ideals. As we know, their concerns are with such immediacies as classroom management, student motivation, assessment strategies, and lesson planning. The problems identified by philosophers of education may seem remote, irrelevant, esoteric, or even quaint. Even students who have spent their undergraduate years wrestling with intellectual ideas that had no immediate bearing on their lives find the enterprise pointless as soon as they enter a professional program in teacher education. Once they begin to listen to teachers in the field, their suspicions about philosophy's dubious relation to "the real world" of practice are often confirmed.

Entwistle cautions us against too hastily blaming aspiring teachers or practicing teachers for this out-of-hand dismissal of theory. What he only hints at, however, is how the dismissal relates to the conception of teaching so many people are gripped by. The roots of aspiring teachers' beliefs about teaching and learning to teach are deeply embedded. The beliefs can be nearly unshakeable parts of their identity as people who want to be teachers, beliefs shaped by a lifetime in schools and in societies in which certain views of what a teacher does and should do, seem steadfast.

In a review of Carl Sagan's book, The Demon-Haunted World: Science as a Candle in the Dark, Richard Lewontin tells a story of the time when he and Sagan were persuaded to take the affirmative side in a debate about the veracity of evolutionary theory in front of an "immense audience of creationist fundamentalist Christians" in Little Rock, Arkansas. ${ }^{8}$ Despite their "absolutely compelling arguments" the audience voted with the opposition and rejected Darwinism. Lewontin and Sagan drew entirely different lessons from the experience: Sagan, believing that the struggle was one between ignorance and knowledge, went on to make a career of popularizing science and scientific theories. Lewontin, however, believed that the, "confrontation between creationism and the science of evolution was an example of historical, regional and class differences in cultures that could only be understood in the context of American social history." 9 On his view, rural, traditionally minded working class folks who felt that they were losing control of their children to the State and to the blasphemous values of urban,

\footnotetext{
8 Richard Lewontin, "Billions and billions of demons," New York Times Book Reviens, January 9, 1997. Retrieved October 28, 2002 from http://www.csus.edu/indiv/m/mayesgr/Lewontin1.htm.

${ }^{9}$ Lewontin, no pages given.
} 
Northern intellectuals, quite understandably drew a line in the sand. The lesson he drew was that people (including scientists) believe things (including irrational things) and hold onto beliefs because of factors that have little to do with weighing evidence and evaluating reasons, and everything to do with power, identity, and solidarity.

I bring up the story not only because Sagan's piece on "Wonder and Skepticism" is testimony to his pursuit of making scientific knowledge accessible. Nor do I bring it up as a harbinger of current debates about "Intelligent Design." I introduce the story because of what it tells us about aspiring teachers' reluctance to be "appropriately moved by reasons" and so come to change their beliefs about the nature of schooling and learning to teach. Many aspiring teachers quite naturally align themselves with members of the culture they are entering, and quite sensibly take to heart concerns about the everyday realities they hear of in staff rooms. When practicing teachers question the value of theory for their practices, why shouldn't student teachers believe them? To put the matter slightly differently, and in Lewontin's language, the issue is one of power. It is not an irrelevant fact that philosophers of education are not the people who hire teachers. Does this mean that the writers who have contributed to Philosophy of Education have little to say that aspiring teachers are able or inclined to hear? I think they have much to say, but I also think helping students pay serious attention to philosophical questions about education is a long and winding road.

\section{Philosophy as Education}

Philosophers of education ask student teachers to confront a daunting amount of intellectual uncertainty while turning over prior assumptions about teaching and learning. The request to enter philosophical discussions can be met with resistance ("why do we have to learn this stuff?") bewilderment ("what are they talking about?") and if we are very fortunate, genuine curiosity, and willingness to engage with ideas. Some puzzlement expressed by students is due to the fact that they enter the middle of ongoing conversations (in Oakeshott's sense) about ideas that have past as well as present lives. Most often these students have no historical context for these conversations or for the conflicting values and contested concepts that initiated and still fuel debates. Bernard Williams writes,

In any area of philosophy, the concern that gets reflection going, the failure to understand ourselves, must start from where we are... and it starts from now. The concepts that give rise to the question are ours. But there is a story behind those concepts: a history of how people have come to think like this. ${ }^{10}$

If history is essential to philosophical understanding, little wonder students are bewildered by what they hear. Typically, the discussants don't pause to fill students in. Further, according to Williams, "Many philosophers do have some respect for the history of philosophy; what matters more is their neglect of another history - the history of the concepts which philosophy is trying to understand." This includes concepts associated with education: equality, distributive justice, integration, indoctrination, and so on.

Resistance, another common response to learning, is complicated, as Joyce Bellous reminds us in her contribution to this collection. As suggested earlier, resistance to philosophy may come from students' narrow expectations of teacher education, or from eagerness to identify with the culture of practitioners, not theoreticians. It may come from their sense that if experts haven't resolved (and may never resolve) contentious issues, their own participation in the arguments would be pointless. They may conclude that if no one agrees on an answer, one opinion must be just as valid as another.

\footnotetext{
${ }^{10}$ Bernard Williams, "Why philosophy needs history," London Review of Books (Oct.17, 2002), 24, $20,7$.
} 
Is there hope for a response other than the subjectivist's view that "any belief is as good as any other," or the dismissal of philosophical projects as overwhelmingly perplexing or irrelevant? I think hope is found in the notion of becoming a philosopher of one's own education, becoming attentive, even vigilant to the possibilities for self-discovery, both in terms of learning and unlearning. Ann Diller explores three capacities worth cultivating in this regard, and notes this is only a start. ${ }^{11}$ On her view, the first two capacities relate to perspective taking, what she calls the perspective of distance (being able to step back far enough to see patterns and take a wider view of circumstance) and the perspective of angles (imagining a situation from a fresh viewpoint or someone else's viewpoint). While acknowledging the difficulties in talking about a more distant view of experience, she writes that without this perspective, "most students will, I suspect, remain mired either in their existing educational tracks or else in their reactive responses against these." 12 The third capacity she suggests is the readiness to be perplexed, even shocked into uncertainty, what she terms the "capacity to be torpified," following Meno's reaction to Socrates' ability, in the manner of a "torpedo fish," to shake peoples' certainty about even their most deeply- held convictions. Building on these three, I offer three related capacities, which, if cultivated, may help students become philosophers of their own educations:

1. The capacity to hold convictions humbly. In the interview reprinted in Philosophy of Education, Freire says that humility is an important virtue for a teacher, and this sentiment is echoed elsewhere. It is indispensable to listening seriously to other people, to uncovering one's assumptions, and to changing one's mind. As Thayer- Bacon reminds us, we are "fallible, embedded and embodied social beings. None of us has justified grounds to claim omniscience." 13 While related to capacities for perspective taking, this disposition is explicitly moral as well as intellectual, calling for respectful regard.

2. The capacity to engage with history. At the same time I was reading Philosophy of Education, I rediscovered the book, Philosophers on Education. ${ }^{14} \mathrm{I}$ was repeatedly moved by the writers' deep respect for their subjects of study, and their acknowledgement of indebtedness to the work of the philosophers discussed. I think philosophers of education need to be equally vigilant about acknowledging our debts to the past (and our departures) and providing historical context so students see why people have cared so deeply about educational aims and means. When they do, and there are examples in Hare \& Portelli's collection, we are rewarded with a wider view of experience -the distance Diller encourages.

3. The capacity to embrace complexity. This is similar to, yet distinct from, the "capacity to be torpified": it admits the difficulty of making sense of complex phenomena, multilayered ideas, even multiple realities, and calls for the next step toward growth in understanding. Cognitive dissonance must be productive, not paralyzing. ${ }^{15} \mathrm{We}$ cannot stay in shock; we have to find a way to move forward (even when confronted with the limitations of philosophy Bittings points to.)

\footnotetext{
${ }^{11}$ Diller, no pages given.

12 Ibid, no pages given.

${ }^{13}$ Barbara Thayer- Bacon, "Constructive thinking vs. critical thinking," in W. Hare and J.Portelli (eds.), Philosophy of Education: Introductory Readings, Revised Third Edition (Calgary: Detselig Ent. Ltd., 2001), 211.

${ }^{14}$ Amelie Rorty (ed.), Philosophers on Education: New Historical Perspectives (London: Routledge, 1998).

${ }^{14}$ See Nicholas C. Burbules, "2001: A philosophical odyssey," in S. Rice (ed.), Philosophy of Education 2001 (Urbana, Ill.: Philosophy of Education Society, 2002), 1-14.

${ }^{15}$ Amelie Rorty, 1.
} 
Taken together, the capacities speak to the need for students to make the knowledge they encounter genuinely their own. Diller believes students may sometimes express one or more capacities in ways we don't typically recognize, in fleeting moments that can be shaped into opportunities for discovery instead of instances of rebellion. I think the capacities can't be taught outright, but they can be both modeled and nurtured by the people who are already inside the practice of philosophizing about education, including their own philosophies. The philosophers of education who appear in Philosophy of Education can be seen as exemplars. Modeling is one of the goods a book like this provides. But I expect that in most cases, it will take something other than reading for students to see that their own questions about professional identity, pedagogical responsibilities, and curricular content, fit into a much larger context. There will be numerous events and critical junctures in classrooms (on campus and in schools) that can, if they are open to them, move students toward genuine doubt and reflection. Sensitive teachers can turn students' attention toward these possibilities and then toward the philosophical conversations that extend them.

Philosophers of education often model through their practices the capacities Diller identifies. But there is one practice that may work against efforts to cultivate these capacities in students. Philosophers of education often attempt to build the bridges between theory and practice that aspiring teachers ask for. We try to build them by using our own architectural blueprints - our own knowledge and purposes - and through argument, narrative and debate, we hope these constructions will be passed on. This bridge building is evident in much of Hare \& Portelli's collection. However, aspiring teachers need to build their own bridges between theory and practice; these are the connections they need to find for themselves, and fit to their particular contexts. They need to make the knowledge their own, to engage with it as philosophers of their own educations. Amelie Rorty writes that, "Philosophy is implicitly pedagogical." 16 I believe that to try to make explicit to our students, the (implicit) usefulness of philosophy to education is a mistake for two reasons. First, our efforts will rarely if ever resonate with students' particular circumstances. And, second, students won't own the knowledge. As philosopher Alan Ryan observes from his viewpoint on educational history, "The vice of philosophers traditionally had been to think of all knowledge as spectatorial; Deweyan education started from the view that knowing was a form of engaging with the world." ${ }^{17}$ It's a useful reminder for us all.

\footnotetext{
16 Alan Ryan, "Deweyan Pragmatism and American education," in Amelie Rorty (ed.), Philosophers on Education: New Historical Perspectives. (London: Routledge, 1998), 399.

17 Alan Ryan, "Deweyan Pragmatism and American education," in Amelie Rorty (ed.), Philosophers on Education: New Historical Perspectives. (London: Routledge, 1998), 399.
} 